\title{
Research Paper Input utilization in tur production - a production function analysis
}

\author{
- H.J. WAGH, J.A. LAMTULE AND M.M. KADAM
}

See end of the paper for authors' affiliations

Correspondence to :

H.J. WAGH

Department of

Agricultural Economics

and Statistics, Post

Graduate Institute, Dr.

Punjabrao Deshmukh

Krishi Vidyapeeth, AKOLA

(M.S.) INDIA

Email:

harshwagh25@yahoo.com

Paper History :

Received : 08.04 .2014

Revised : 24.07.2014;

Accepted: 08.08.2014
ABSTRACT : Vidarbha agriculture is known as Kharif prone area as the crops solely dependent on the rains. The pulses production programme has attracted the Vidarbha farmers and tur (pigeanpea/redgram) is cultivated with cotton. Akola is pre-dominantly known as Kharif prone region. The capital management in tur production is mostly high labour input oriented and as such the productivity of tur is below the state average. With this view, the investigation was carried out in Akola district, to study the inputs used in tur production, the share of each inputs and its contribution in tur productivity and to study the input-output relationship in tur production. The study was based on data for the year 2011-12, collected by cost accounting method under agricultural prices and cost scheme. The study concluded that the per cent share of inputs to expenditure was 42.04 per cent of human labour, 21.73 per cent machine power and 17.65 per cent bullock labour. The contribution of the selected variables in determining the productivity was 28.61 per cent of human labour, 17.50 per cent of seed, 40.07 per cent of machine power and the 14.36 per cent of bullock labour. The relationship between human labour, bullock labour, machine power and seed productivity was found to be significant. Production function analysis revealed that, decreasing returns to scale (0.89) was observed in tur production with the value of $\mathrm{R}^{2}(0.69)$, indicating variables under study have explained 69 per cent contribution in tur production.

KEY WORDS : Input-output, Expenditure, Correlation, Cobb- Douglas production function

HOW TO CITE THIS PAPER : Wagh, H.J., Lamtule, J.A. and Kadam, M.M. (2014). Input utilization in tur production a production function analysis. Internat. Res. J. Agric. Eco. \& Stat., 5(2) : 253-256. 